\title{
ASSESSMENT OF HEALTH RISK BY WIND CHILL FACTOR IN THE KRASNOYARSK KRAI
}

\author{
Rakhmanov RS ${ }^{1} \bowtie$, Bogomolova ES ${ }^{1}$, Narutdinov DA², Badeeva TV ${ }^{1}$
}

1 Department of Hygiene Volga Research Medical University, Nizhny Novgorod, Russia

${ }^{2}$ Medical unit of military unit 73633, Krasnoyarsk, Russia

\begin{abstract}
Wind affects functional state and health of human beings. Physical activity mitigates the risk of hypothermia, but not the discomfort felt in cold winds. Moreover, there appears a risk of body cooling and frostbite. This study aimed to assess the risk to health of a human being associated with the wind chill factor index in the various climatic zones of a Russian region. The calculation relied on the mean monthly daily temperature and wind speed values, minimum temperature and maximum wind values registered in the subarctic and continental climate zones during the two climatological normals determination observation periods, 1961 1990 (second period) and 1991-2020 (third period). In the third period, a significant decrease in wind strength was registered in the subarctic (8 months) and temperate continental (9 months) climates. The mean monthly temperatures increased in April by $3.5^{\circ} \mathrm{C}(p=0.006)$, April-June by $4.05^{\circ} \mathrm{C}(p=0.001)$ and $3.9^{\circ} \mathrm{C}$ $(p=0.001)$. The maximum wind in the subarctic climate did not change, in the temperate continental zone it decreased within 9 months; the minimum temperature increased in 4 and 1 months. In the subarctic zone, the mean temperature and wind values made the ambient conditions uncomfortable for 6 months (versus 7), with one characterized as "extremely cold"; the cold exposure risk decreased during the "very cold" period; in the temperate climate zone, the potentially uncomfortable conditions period lasted for 4 months (versus 6). With wind at the maximum and temperature at the minimum, in the subarctic climate, the weather remained severe for 8 months a year in each of the determination periods ("uncomfortable, chilly" -2 months, "cold, skin surface hypothermia" -1 month, "extremely cold, possible hypothermia of the exposed parts of the body in 10 minutes" -5 months); in the temperate continental climate zone, it was severe for 5 months of each year ("uncomfortable, chilly" -2 months, "cold, skin surface hypothermia" -3 month).
\end{abstract}

Keywords: wind chill factor; subarctic, continental climate; Krasnoyarsk Krai, health risk

Author contribution: Rakhmanov RS — study conceptualization and design, report authoring, editing; Bogomolova ES — literature data collection, report editing; Narutdinov DA - material collection and systematization; Badeeva TV — material processing, participation in the processing of the results, report text preparation. All co-authors agreed and approved the final version of the report.

$\triangle$ Correspondence should be addressed: Rofail S. Rakhmanov ploschad Minina i Pozharskogo, 10/1, Nizhny Novgorod, 603005; raf53@mail.ru

Received: 23.12.2020 Accepted: 19.01.2021 Published online: 01.02.2021

DOI: $10.47183 /$ mes.2021.002

\section{ОЦЕНКА РИСКА ЗДОРОВЬЮ ПО ВЕТРО-ХОЛОДОВОМУ ИНДЕКСУ НА ТЕРРИТОРИИ КРАСНОЯРСКОГО КРАЯ}

\author{
Р. С. Рахманов ${ }^{\natural}$, Е. С. Богомолова ${ }^{1}$, Д. А. Нарутдинов ${ }^{2}$, Т. В. Бадеева ${ }^{1}$
}

${ }^{1}$ Приволжский исследовательский медицинский университет, Нижний Новгород, Россия

${ }^{2}$ Медико-санитарная часть войсковой части 73633, Красноярск, Россия

\begin{abstract}
Ветер влияет на функциональное состояние, здоровье человека. При холодном ветре активность смягчает риск гипотермии, но не дискомфорт, возникает угроза охлаждения организма и обморожений. Целью работы было оценить риск здоровью человека, возникающий при проживании в различных климатических зонах региона России по ветро-холодовому индексу. Расчет проводили по среднемесячным значениям суточной температуры и скорости ветра, минимальной температуры и максимального ветра в субарктическом и континентальном климате в периодах определения климатических норм: 1961-1990 гг. (второй период) и 1991-2020 гг. (третий период). В третьем периоде установлено достоверное снижение силы ветра в субарктическом (8 месяцев) и умеренном континентальном (9 месяцев) климате. Среднемесячные температуры увеличивались в апреле на 3,5 ㅇ ( $p=0,006)$, апреле-июне на $4,05^{\circ} \mathrm{C}(p=0,001)$ и 3,9 ${ }^{\circ} \mathrm{C}(p=0,001)$. Максимальный ветер в субарктическом климате не изменился, в умеренном снизился в течение 9 месяцев; минимальная температура возросла в течение 4 и 1 месяца. По средним значениям температуры и ветра в субарктическом поясе 6 месяцев (против 7) возникали дискомфортные ощущения, в том числе 1 месяц как «чрезвычайно холодно»; уменьшился риск холодового воздействия за счет «очень холодно»; в умеренном поясе риск дискомфортных ощущений был зарегистрирован 4 месяца (против 6). При максимальном ветре и минимальной температуре жесткость погоды в субарктическом климате в каждом периоде сохранялась 8 месяцев в году («дискомфорт, прохлада» — 2, «холодно, переохлаждение поверхности кожи» - 1, «чрезвычайно холодно, обнаженные части тела могут переохладиться за 10 мин» — 5); в умеренном 5 месяцев («дискомфорт, прохлада» — 2, «очень холодно, переохлаждение поверхности кожи» - 3).
\end{abstract}

Ключевые слова: ветро-холодовой индекс, субарктический климат, континентальный климат, Красноярский край, риск здоровью

Вклад авторов: Р. С. Рахманов — концепция и дизайн исследования, написание текста, редактирование; Е. С. Богомолова - сбор данных литературы, редактирование статьи; Д. А. Нарутдинов - сбор и систематизирование материала; Т. В. Бадеева - обработка материала, участие в интерпретации результатов, подготовке текста статьи. Все соавторы согласовали и утвердили окончательный вариант статьи.

$\bowtie$ Для корреспонденции: Рофаиль Салыхович Рахманов пл. Минина и Пожарского, д. 10/1, г. Нижний Новгород, 603005; raf53@mail.ru

Статья получена: 23.12.2020 Статья принята к печати: 19.01.2021 Опубликована онлайн: 01.02.2021

DOI: $10.47183 /$ mes.2021.002

Being outdoors and in the open, a person is directly exposed to weather conditions, which affect, first of all, his/her thermal status. There is a number of weather-related factors that shape our perception of how warm we are: temperature, air movement speed, humidity, pressure, atmosphere's electrical status, radiation temperature, etc. The wind does not change the ambient temperature, but it does draw heat off the body of a human being. Cold wind alters how we perceive ambient temperature: the faster heat is drawn off the body, the colder it feels $[1,2]$.

Wind can have both sanogenic and negative effects on all aspects of life and health of a human being. The conditions that largely shape our feeling of comfort when outdoors in the open largely depend on wind; it redistributes moisture above 
Table 1. Wind speed values in the subarctic climate, $\mathrm{m} / \mathrm{s}$

\begin{tabular}{|c|c|c|c|c|c|c|c|c|c|c|c|c|c|c|}
\hline \multirow{2}{*}{ Observation } & \multicolumn{10}{|c|}{ Wind speed by months of the year, $\mathrm{M} \pm m$} \\
\cline { 2 - 14 } & 1 & 2 & 3 & 4 & 5 & 6 & 7 & 8 & 9 & \multicolumn{1}{|c|}{10} & 11 & 12 \\
\hline \multicolumn{10}{|c|}{ Average monthly daily speed } \\
\hline 1 & $5.2 \pm 0.4$ & $5.6 \pm 05$ & $5.8 \pm 0.3$ & $5.7 \pm 0.3$ & $5.0 \pm 0.3$ & $5.0 \pm 0.2$ & $4.4 \pm 0.2$ & $4.3 \pm 0.2$ & $4.5 \pm 0.4$ & $5.1 \pm 0.3$ & $5.5 \pm 0.4$ & $6.1 \pm 0.2$ \\
\hline 2 & $5.0 \pm 0.3$ & $4.6 \pm 0.4$ & $4.8 \pm 0.4$ & $4.8 \pm 0.2$ & $4.2 \pm 0.1$ & $4.2 \pm 0.1$ & $3.6 \pm 0.05$ & $3.6 \pm 0.1$ & $3.6 \pm 0.2$ & $4.3 \pm 0.3$ & $4.4 \pm 0.3$ & $5.4 \pm 0.2$ \\
\hline$p$ & 0.68 & 0.09 & 0.71 & 0.018 & 0.14 & 0.001 & 0.001 & 0.015 & 0.02 & 0.048 & 0.041 & 0.05 \\
\hline \multicolumn{10}{|c|}{ Average monthly maximum speed } \\
\hline 1 & $15.5 \pm 0.6$ & $13.9 \pm 0.7$ & $14.3 \pm 1.0$ & $14.5 \pm 0.6$ & $12.3 \pm 0.9$ & $12.8 \pm 0.6$ & $12.1 \pm 0.5$ & $10.5 \pm 0.4$ & $13.5 \pm 1.1$ & $14.3 \pm 0.9$ & $14.2 \pm 0.8$ & $16.2 \pm 0.7$ \\
\hline 2 & $16.3 \pm 0.8$ & $14.1 \pm 0.7$ & $16.9 \pm 1.0$ & $14.0 \pm 0.9$ & $12.8 \pm 0.5$ & $12.9 \pm 0.9$ & $10.9 \pm 1.0$ & $11.2 \pm 0.9$ & $12.2 \pm 1.4$ & $13.6 \pm 1.0$ & $14.4 \pm 0.9$ & $15.4 \pm 0.6$ \\
\hline$p$ & 0.41 & 0.83 & 0.14 & 0.14 & 0.64 & 0.92 & 0.278 & 0.252 & 0.469 & 0.61 & 0.86 & 0.4 \\
\hline
\end{tabular}

the planet's surface, equalizes the temperature, purifies the air. Strong wind puts pressure on the surface tissues of the body, causes fatigue, headaches, anxiety, insomnia, hinders breathing, aggravates shortness of breath, and has a depressing effect on the human psyche. Such wind also contributes to dust formation and carries it over considerable distances. When it lifts droplets of water from the surface of seas and lakes into the air, strong wind plays its role in the spreading of infectious diseases [3]. Wind should be considered decisive factor in the transmission of a wide range of diseases and not just airborne, since it can modulate the dynamics of various spreaders and pathogens [4-7].

With wind's contribution, weather has direct or indirect effect on the functional state of a human being, shapes the overall health status in a population, conditions regional peculiarities of the diseases influenced by climatic factors [8-11]. Among the numerous bioclimatic indicators, the "cold stress" indices are distinguished as factors limiting the duration of a person's stay in the open in winter $[12,13]$. Some researchers give preference to the Siple's wind chill factor (WCF) in assessment of influence of the cold [14, 15]. Determining the WCF allows identification of the possible health risks associated with low temperatures and cold winds [16-19].

This study aimed to assess the risk to health of a human being associated with the wind chill factor index in the various climatic zones of Krasnoyarsk Krai.

\section{METHODS}

Retrospectively, based on the long-term observation data and through the lens of the Siple's wind chill factor [20] (WCF), we assessed the risks the cold peculiar to subarctic and temperate continental climate zones of the Krasnoyarsk Krai presents to a human being upon exposure. The cold stress risk scale was as follows: from -10 to $-24{ }^{\circ} \mathrm{C}-$ uncomfortable, chilly; from

Table 2. Wind speed values in the temperate continental climate, $\mathrm{m} / \mathrm{s}$
-25 to $-34^{\circ} \mathrm{C}$ - very cold, skin surface hypothermia; from -35 to $-59^{\circ} \mathrm{C}$ - extremely cold, possible hypothermia of exposed parts of the body in 10 minutes, and $-60^{\circ} \mathrm{C}$ down - extremely cold, possible hypothermia of exposed parts of the body in 2 minutes [21].

The World Meteorological Organization (1962) adopted 30year periods for determination of climatological normals: the first from 1931 to 1960, the second from 1961 to 1990 , and the third from 1991 to 2020. Our study relied on the data covering the last two of such periods, 1961-1990 (second period) and 1991-2020 (third period) [22, 23]. We assessed the average monthly daily temperature and wind speed values in the open as registered during the last 10 years of each determination period, 1981-1990 and 2010-2019, respectively. We also assessed the monthly average minimum temperature and maximum wind speed indicators. Meteorological information was obtained from the Central Siberian Department for Hydrometeorology and Environmental Monitoring, located in Norilsk (Taimyr Branch) and Krasnoyarsk (Experimental Field). Wind strength was assessed in points on the Beaufort scale [24].

The data was statistically processed with Statistica 6.0 (StatSoft; USA); we determined mean values and standard errors $(M \pm m)$, applied Student's $t$-test. The differences were considered significant at $p<0.05$.

\section{RESULTS}

Assessing the average monthly wind speeds in the subarctic climate, we noticed that in the second climatological normals determination period (1961-1990) its strength was put at 3 points (from weak to moderate) for 7 months a year (May October and January): from $4.3 \pm 0.2$ to $5.1 \pm 0.2 \mathrm{~m} / \mathrm{s}$ (Table 1). In the remaining 5 months, it was given 4 points (moderate): from $5.5 \pm 0.4$ to $6.1 \pm 0.2 \mathrm{~m} / \mathrm{s}$. In the third period (1991-2020), for 11 months a year (except December) the wind strength's

\begin{tabular}{|c|c|c|c|c|c|c|c|c|c|c|c|c|}
\hline \multirow{2}{*}{ Observation } & \multicolumn{12}{|c|}{ Wind speed by months of the year, $\mathrm{M} \pm m$} \\
\hline & 1 & 2 & 3 & 4 & 5 & 6 & 7 & 8 & 9 & 10 & 11 & 12 \\
\hline \multicolumn{13}{|c|}{ Average monthly daily speed } \\
\hline 2 & $2.4 \pm 0.1$ & $2.3 \pm 0.2$ & $2.8 \pm 0.3$ & $2.9 \pm 0.2$ & $2.7 \pm 0.2$ & $2.2 \pm 0.2$ & $1.7 \pm 0.07$ & $1.7 \pm 0.05$ & $1.9 \pm 0.1$ & $2.6 \pm 0.2$ & $3.0 \pm 0.2$ & $2.7 \pm 0.2$ \\
\hline 3 & $1.8 \pm 0.2$ & $1.9 \pm 0.08$ & $2.1 \pm 0.1$ & $2.3 \pm 0.1$ & $2.1 \pm 0.07$ & $1.6 \pm 0.07$ & $1.4 \pm 0.05$ & $1.5 \pm 0.09$ & $1.7 \pm 0.1$ & $2.0 \pm 0.16$ & $2.0 \pm 0.13$ & $1.9 \pm 005$ \\
\hline$p$ & 0.04 & 0.045 & 0.017 & 0.014 & 0.003 & 0.009 & 0.04 & 0.038 & 0.87 & 0.029 & 0.001 & 0.001 \\
\hline \multicolumn{13}{|c|}{ Average monthly maximum speed } \\
\hline 2 & $9.8 \pm 0.4$ & $8.6 \pm 0.3$ & $8.4 \pm 0.4$ & $8.3 \pm 0.4$ & $8.1 \pm 0.4$ & $6.8 \pm 0.4$ & $6.1 \pm 0.3$ & $5.4 \pm 0.3$ & $7.0 \pm 0.4$ & $8.1 \pm 0.3$ & $10.1 \pm 0.1$ & $10.0 \pm 0.4$ \\
\hline 3 & $7.3 \pm 0.6$ & $7.3 \pm 0.2$ & $6.5 \pm 0.2$ & $6.7 \pm 0.3$ & $6.9 \pm 0.7$ & $5.1 \pm 0.4$ & $4.8 \pm 0.2$ & $5.3 \pm 0.5$ & $6.0 \pm 0.4$ & $6.9 \pm 0.4$ & $7.0 \pm 0.3$ & $7.9 \pm 0.2$ \\
\hline$p$ & 0.002 & 0.002 & 0.001 & 0.008 & 0.15 & 0.007 & 0.002 & 0.226 & 0.1 & 0.01 & 0.001 & 0.001 \\
\hline
\end{tabular}


Table 3. Ambient temperature values in the subarctic climate, ${ }^{\circ} \mathrm{C}$

\begin{tabular}{|c|c|c|c|c|c|c|c|c|c|c|c|c|}
\hline \multirow{2}{*}{ Observation } & \multicolumn{12}{|c|}{ Ambient temperature by months of the year, $\mathrm{M} \pm m$} \\
\hline & 1 & 2 & 3 & 4 & 5 & 6 & 7 & 8 & 9 & 10 & 11 & 12 \\
\hline \multicolumn{13}{|c|}{ Average monthly daily temperature } \\
\hline 2 & $-23.8 \pm 2.2$ & $-21.8 \pm 1.7$ & $-16.3 \pm 1.0$ & $-10.8 \pm 1.6$ & $0.2 \pm 0.3$ & $11.4 \pm 1.9$ & $19.9 \pm 1.2$ & $15.6 \pm 0.6$ & $7.6 \pm 0.8$ & $-4.6 \pm 0.6$ & $-18.0 \pm 2.1$ & $-20.5 \pm 1.7$ \\
\hline 3 & $-23.3 \pm 1.5$ & $-21.5 \pm 1.7$ & $-16.5 \pm 1.7$ & $-7.3 \pm 0.9$ & $1.6 \pm 1.0$ & $15.3 \pm 1.0$ & $19.9 \pm 0.9$ & $15.2 \pm 0.8$ & $8.2 \pm 0.9$ & $-3.6 \pm 0.9$ & $-17.8 \pm 1.2$ & $-18.0 \pm 1.4$ \\
\hline$p$ & 0.83 & 0.905 & 0.119 & 0.006 & 0.31 & 0.062 & 0.962 & 0.707 & 0.649 & 0.464 & 0.926 & 0.29 \\
\hline \multicolumn{13}{|c|}{ Average monthly minimum temperature } \\
\hline 2 & $-30.2 \pm 2.1$ & $-29.0 \pm 1.2$ & $-26.2 \pm 1.2$ & $-19.2 \pm 1.5$ & $-7.8 \pm 0.5$ & $3.3 \pm 0.8$ & $10.3 \pm 0.7$ & $7.8 \pm 0.7$ & $1.0 \pm 0.5$ & $-11.5 \pm 1.2$ & $-24.9 \pm 1.7$ & $-27.8 \pm 1.4$ \\
\hline 3 & $-30.5 \pm 1.6$ & $-30.5 \pm 1.7$ & $-20.4 \pm 2.0$ & $-13.5 \pm 0.9$ & $-5.4 \pm 0.8$ & $6.5 \pm 0.6$ & $11.2 \pm 0.6$ & $7.8 \pm 0.6$ & $2.2 \pm 0.6$ & $-8.9 \pm 1.2$ & $-24.8 \pm 1.1$ & $-25.3 \pm 1.5$ \\
\hline$p$ & 0.92 & 0.86 & 0.014 & 0.005 & 0.024 & 0.007 & 0.36 & 0.98 & 0.366 & 0.146 & 0.92 & 0.24 \\
\hline
\end{tabular}

score was 3 points: from $3.6 \pm 0.1$ to $5.4 \pm 0.2 \mathrm{~m} / \mathrm{s}$. With the exception of winter months, i.e. for 8 months in a year, the speed of air movement was registered decreasing significantly. The average monthly maximum wind speed values did not change. The lowest values were recorded in August (10.5 \pm 0.4 and $11.2 \pm 0.9 \mathrm{~m} / \mathrm{s} ; p=0.252)$, the highest in December $(16.2 \pm 0.7$ and $15.4 \pm 0.6 \mathrm{~m} / \mathrm{s} ; p=0.4)$ and January $(15.5 \pm 0.6$ and $16.3 \pm 0.8 \mathrm{~m} / \mathrm{s} ; p=0.41$ ). In July and September, they were $1.2-1.3 \mathrm{~m} / \mathrm{s}$ less, but the difference with the values recorded in the previous determination period were insignificant: $10.9 \pm 1.0$ versus $12.1 \pm 0.5 \mathrm{~m} / \mathrm{s}(p=0.278)$ and $12.2 \pm 1.4 \mathrm{~m} / \mathrm{s}$ versus $13.5 \pm 1.1 \mathrm{~m} / \mathrm{s}(p=0.469)$.

In the temperate continental climate, the wind was given 2 points (weak wind) in all months of the year: from $1.7 \pm 0.07 \mathrm{~m} / \mathrm{s}$ to $3.0 \pm 0.2 \mathrm{~m} / \mathrm{s}$ (Table 2). In Junes and Julys of the third period it scored 1 point (very weak): from $1.4 \pm 0.05$ to $1.5 \pm 0.09 \mathrm{~m} / \mathrm{s}$. With the exception of one month (September), there was a significant decrease in wind strength. Nine months of the third period (except for May, August and September) saw a significant decrease in the maximum wins speed. This decrease ranged from $1.0 \mathrm{~m} / \mathrm{s}$ in February and June $(p=0.002)$ to $3.1 \mathrm{~m} / \mathrm{s}$ in November ( $p=0.001)$ and $2.5 \mathrm{~m} / \mathrm{s}$ in January $(p=0.002)$.

In the summer months of the second climatological normals determination period, the average daily air temperature in the subarctic climate ranged from $11.4 \pm 1.9$ to $19.9 \pm 1.2^{\circ} \mathrm{C}$, in the winter months - from $-20.5 \pm 1.7$ to $-23.8 \pm 2.2^{\circ} \mathrm{C}$ (Table 3). In the third period, compared to the data registered in the previous periods, it grew by $3.5^{\circ} \mathrm{C}$ in April, which is a significant increase $\left(-7.3 \pm 0.9\right.$ versus $\left.-10.8 \pm 1.6^{\circ} \mathrm{C} ; p=0.006\right)$. In June, the temperature increased by $3.9^{\circ} \mathrm{C}$, but this value did not differ significantly from the previous one $(15.3 \pm 1.0$ versus $11.4 \pm 1.9{ }^{\circ} \mathrm{C} ; p=0.062$ ). Besides, in the course of 4 months, March through June, the average monthly minimum temperature was registered increasing: from $-20.4 \pm 2.0$ to $-26.2 \pm 1.2$ $(p=0.014)$ and from $6.5 \pm 0.6$ up to $3.3 \pm 0.8^{\circ} \mathrm{C}(p=0.007)$.

In April and June of the third determination period the average monthly daily air temperature was registered to grow by $4.05{ }^{\circ} \mathrm{C}\left(4.7 \pm 0.5\right.$ versus $\left.0.65 \pm 0.7^{\circ} \mathrm{C} ; p=0.001\right)$ and by $3.9^{\circ} \mathrm{C}\left(18.2 \pm 0.5\right.$ versus $\left.14.3 \pm 0.5^{\circ} \mathrm{C} ; p=0.001\right)$ in April and June, respectively (Table 4). The average monthly minimum temperature difference was recognized as significant only in April $\left(-0.3 \pm 0.4\right.$ versus $\left.-3.5 \pm 0.8^{\circ} \mathrm{C} ; p=0.002\right)$.

Average 5-month WCF values registered in the subarctic climate in the second determination period and 6-month values of the third period show that for human beings, the ambient conditions did not grow uncomfortable (Fig. 1). In the second period, 2 months a year (October and April) saw the conditions assessed as "uncomfortable", the 4 months of November, December, February and March as "very cold", and January as "extremely cold". In the third period, the durations of unfavorable weather conditions changed: the "uncomfortable" period has grown one month (October) shorter, the "very cold" period did not include March anymore, which was marked as uncomfortable, and the period of "extremely cold" conditions remained as it was.

In the temperate continental climate zone, only 6 months (October through March) of the second period years the weather was labeled "uncomfortable", while the third period had only 4 such months (December through February) (Fig. 2).

Maximum wind, combined with minimum temperature, made the conditions less comfortable: the WCF values increased and the weather was perceived more negatively (Table 5). At the same time, for 8 months of each determination period the severity of weather did not change in the subarctic belt. In October and May, WCF made the conditions registered as "uncomfortable, chilly", in April as "very cold, skin surface hypothermia", in November-March as "extremely cold, possible hypothermia of exposed parts of the body in 10 minutes".

In the temperate continental climate, 6 months of the $2^{\text {nd }}$ period had the weather perceived negatively, with 3 of them registering the conditions as "uncomfortable, chilly" and 3 as "very cold, skin surface hypothermia." November could also present conditions described as "uncomfortable." In the climatological normals determination period, the number of months registering weather described as "severe" dropped to 5, with 2 months categorized as "uncomfortable, chilly" and

Table 4. Ambient temperature values in the temperate continental climate, ${ }^{\circ} \mathrm{C}$

\begin{tabular}{|c|c|c|c|c|c|c|c|c|c|c|c|c|}
\hline \multirow{2}{*}{ Observation } & \multicolumn{12}{|c|}{ Air temperature by months of the year, $\mathrm{M} \pm m$} \\
\hline & 1 & 2 & 3 & 4 & 5 & 6 & 7 & 8 & 9 & 10 & 11 & 12 \\
\hline \multicolumn{13}{|c|}{ Average monthly daily temperature } \\
\hline 2 & $-15.3 \pm 0.9$ & $-15.3 \pm 1.7$ & $-5.6 \pm 1.3$ & $0.65 \pm 0.7$ & $9.8 \pm 0.7$ & $14.3 \pm 0.5$ & $18.1 \pm 0.5$ & $15.7 \pm 0.3$ & $9.2 \pm 0.3$ & $1.7 \pm 0.8$ & $-7.7 \pm 1.3$ & $-13.7 \pm 1.4$ \\
\hline 3 & $-17.3 \pm 1.6$ & $-13.9 \pm 1.4$ & $-3.9 \pm 0.9$ & $4.7 \pm 0.5$ & $9.4 \pm 0.5$ & $18.2 \pm 0.5$ & $18.8 \pm 0.3$ & $16.5 \pm 0.3$ & $9.4 \pm 0.5$ & $2.4 \pm 0.9$ & $-7.5 \pm 0.9$ & $-12.6 \pm 2.0$ \\
\hline$p$ & 0.354 & 0.536 & 0.261 & 0.001 & 0.629 & 0.001 & 0.241 & 0.113 & 0.869 & 0.592 & 0.92 & 0.676 \\
\hline \multicolumn{13}{|c|}{ Average monthly minimum temperature } \\
\hline 2 & $-19.3 \pm 1.0$ & $-18.2 \pm 1.3$ & $-9.8 \pm 1.2$ & $-3.5 \pm 0.8$ & $4.4 \pm 0.5$ & $9.4 \pm 0.3$ & $12.7 \pm 0.3$ & $10.7 \pm 0.3$ & $4.6 \pm 0.3$ & $-2.3 \pm 0.7$ & $-10.6 \pm 0.7$ & $-16.2 \pm 1.2$ \\
\hline 3 & $-20.9 \pm 1.5$ & $-20.8 \pm 1.3$ & $-8.8 \pm 0.8$ & $-0.3 \pm 0.4$ & $4.0 \pm 0.4$ & $11.7 \pm 0.3$ & $13.6 \pm 0.3$ & $11.5 \pm 0.3$ & $4.7 \pm 0.5$ & $-1.1 \pm 0.9$ & $-13.5 \pm 1.2$ & $-16.0 \pm 0.2$ \\
\hline$p$ & 0.39 & 0.85 & 0.39 & 0.002 & 0.51 & 0.39 & 0.055 & 0.054 & 0.65 & 0.297 & 0.79 & 0.933 \\
\hline
\end{tabular}


WCF, unit (mean T)

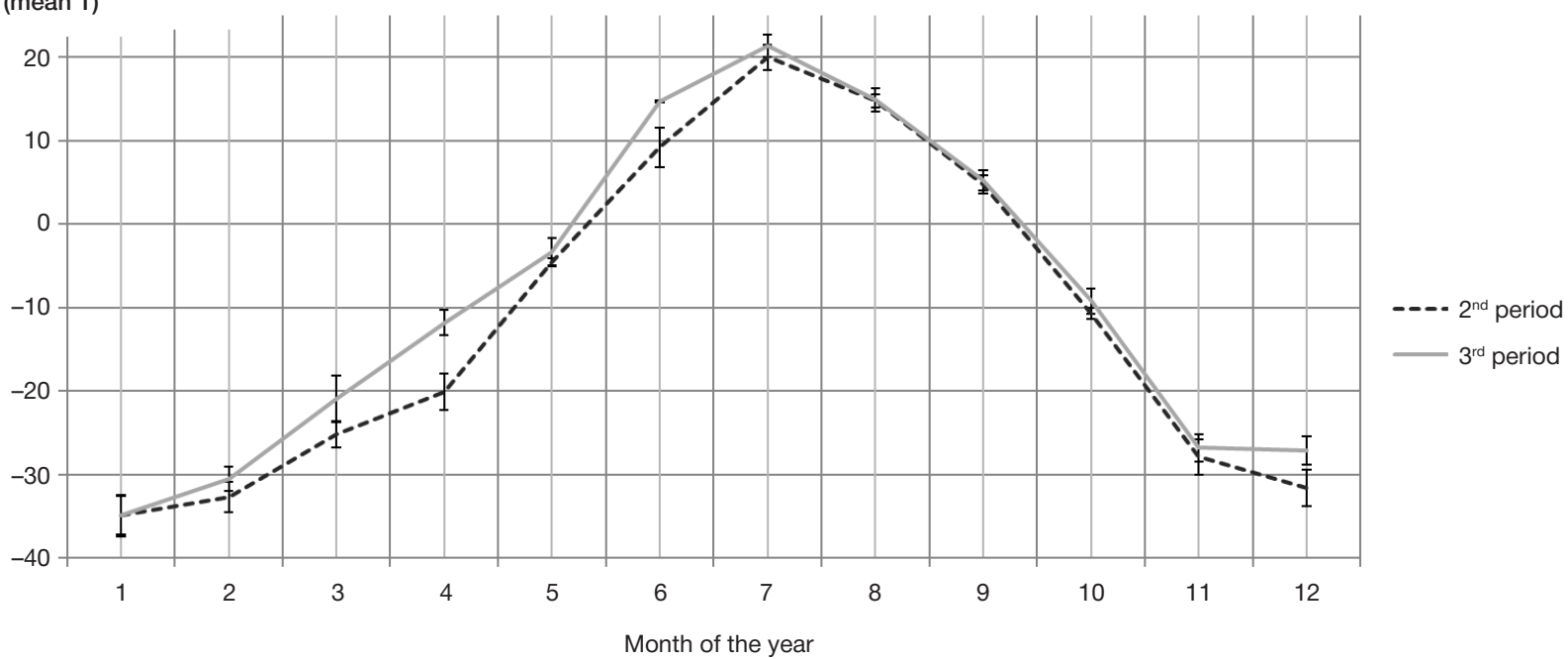

Fig. 1. Wind chill factor curve, average monthly daily ambient temperature and wind speed, subarctic climate, $\mathrm{M} \pm m, \mathrm{units}$

3 falling into the category of "very cold, skin surface hypothermia." It should be noted that in January the WCF value practically reached the "extremely cold, possible hypothermia of exposed parts of the body in 10 minutes" level.

\section{DISCUSSION}

Wind speed is taken into account when determining the conditions applied to work performed outdoors and in unheated rooms, since personal protective equipment is limited in its capacity to prevent onset of hypothermia in harsh climatic conditions (zones "special", IV, III) mainly due to its inefficiency in keeping feet and hands warm and also because of cooling of face and respiratory organs [18, 25, 26]. WCF value is determined for the purposes of preserving health of hikers and athletes practicing winter sports, especially in the northern latitudes of Russia. It is known that the type of activity practiced can mitigate the risk of hypothermia, but it has no effect on the level of discomfort caused by exposure to a cold wind, which poses a risk of body cooling down and frostbite [27, 28]. WCF is also used when establishing the level of comfort in a specific region from the point of view of weather and climatic conditions therein [29]. High wind speeds make walks in the open unsafe without special winter clothing [30]. The severity of a winter correlates with wind strength closely [30, 31].
WCF corresponds to the air temperature in an open area that, with wind blowing at $4.2 \mathrm{~km} / \mathrm{h}$, would have the body cooling down same as it would in the actual ambient conditions [21]. The factor describes the degree of cooling caused by the wind as the air temperature equivalent, the temperature same as that provoking body cooling in the absence of wind, in shade and discounting perspiration. It is not a temperature value but an index that helps relate the cooling effect of wind to air temperature in calm conditions. Wind does not cool an object exposed to it below the temperature of the surrounding air. The faster it blows, the faster such object's temperature will drop to the level of ambient temperature [32]. The weighted average skin temperature of $33^{\circ} \mathrm{C}$ is considered in the body cooling rate calculation. In the absence of any wind and relative humidity at $100 \%$, only the ambient temperature conditions how warm a person feels. If the temperature remains the same but wind picks up and humidity drops, the person's body starts losing heat faster and that person feels as if the temperature was going down. This effect is reversed when wind calms and humidity grows up [33].

Through the considered periods, we discovered that the wind strength decreased in both subarctic and temperate continental climates. These findings are in line with the results reported by other researchers, who also noted that wind speed becomes less dependent on the climatic zone considered [11].

\section{WCF, unit (mean T)}

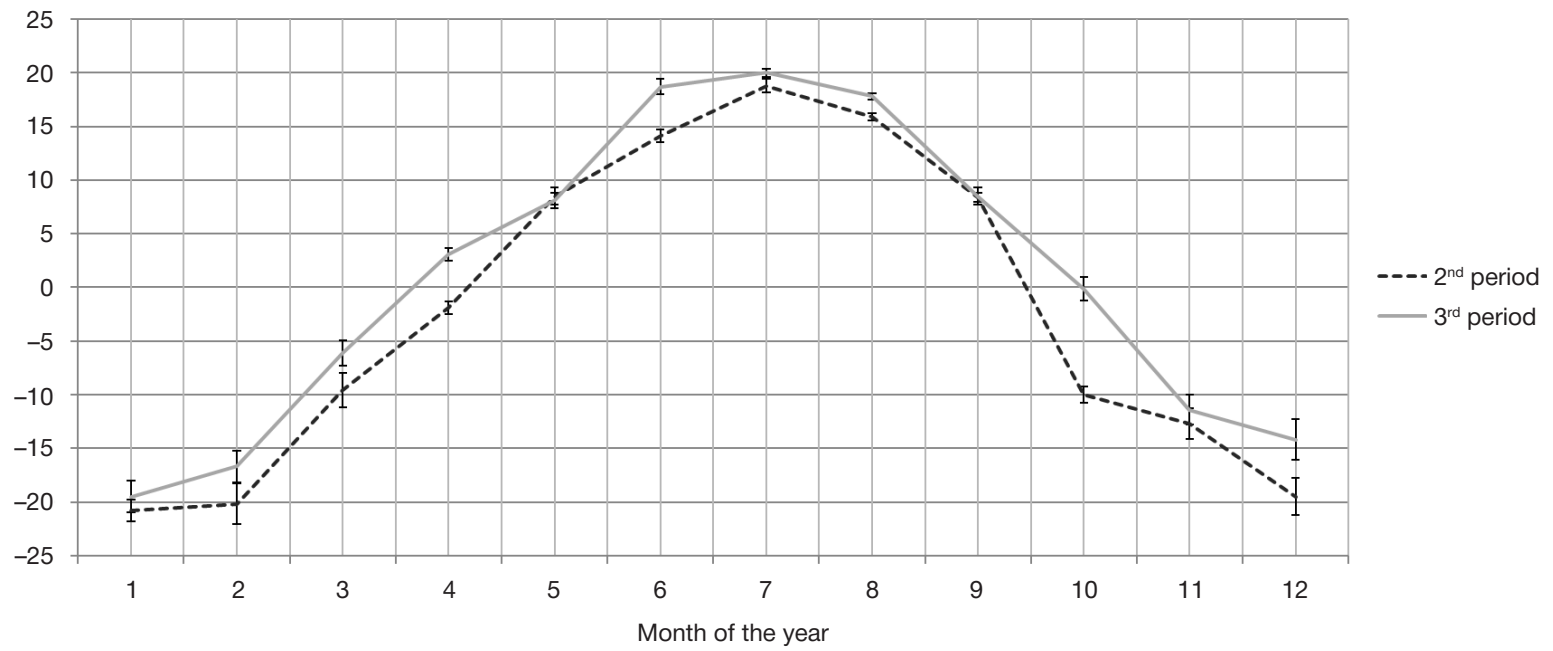

Fig. 2. Wind chill factor curve, average monthly daily ambient temperature and wind speed, temperate continental climate, $M \pm m, u n i t s$ 
Table 5. WCF values peculiar to the combination of minimum temperature and maximum wind strength in different climatic zones, ${ }^{\circ} \mathrm{C}$

\begin{tabular}{|c|c|c|c|c|c|c|c|c|c|}
\hline \multirow{2}{*}{$\begin{array}{c}\text { № } \\
\Pi / \Pi\end{array}$} & \multirow{2}{*}{$\begin{array}{l}\text { Determination } \\
\text { period }\end{array}$} & \multicolumn{8}{|c|}{ Month of the year, $\mathrm{M} \pm m$} \\
\hline & & 1 & 2 & 3 & 4 & 5 & 10 & 11 & 12 \\
\hline 1 & \multicolumn{9}{|c|}{ Subarctic climate } \\
\hline & $2^{\text {nd }}$ period & $-50.1 \pm 2.8$ & $-37.9 \pm 9.9$ & $-44.0 \pm 1.2$ & $-33.9 \pm 2.0$ & $-18.2 \pm 0.6$ & $-20.9 \pm 3.3$ & $-42.1 \pm 2.4$ & $-42.7 \pm 1.9$ \\
\hline & $3^{\text {rd }}$ period & $-50.8 \pm 2.2$ & $-48.1 \pm 2.2$ & $-36.9 \pm 2.6$ & $-26.4 \pm 1.2$ & $-15.2 \pm 1.0$ & $-20.1 \pm 1.5$ & $-41.9 \pm 1.3$ & $-43.2 \pm 2.1$ \\
\hline & $p$ & 0.845 & 0.321 & 0.002 & 0.004 & 0.02 & 0.829 & 0.38 & 0.195 \\
\hline 2 & \multicolumn{9}{|c|}{ Temperate continental climate } \\
\hline & $2^{\text {nd }}$ period & $-32.5 \pm 1.4$ & $-30.3 \pm 1.8$ & $-19.2 \pm 1.5$ & $-11.0 \pm 1.0$ & $-0.7 \pm 0.6$ & $-9.3 \pm 0.9$ & $-21.2 \pm 1.7$ & $-28.5 \pm 1.6$ \\
\hline & $3^{\text {rd }}$ period & $33.9 \pm 2.0$ & $-29.0 \pm 1.8$ & $-16.6 \pm 1.2$ & $-6.1 \pm 0.5$ & $-0.6 \pm 0.6$ & $-7.2 \pm 1.0$ & $-20.1 \pm 1.2$ & $-27.1 \pm 2.7$ \\
\hline & $p$ & 0.577 & 0.621 & 0.152 & 0.001 & 0.953 & 0.142 & 0.61 & 0.66 \\
\hline
\end{tabular}

The researchers have also registered growth of the summer temperature levels. We have also witnessed a significant temperature increase in both climates, but in the subarctic zone such increase was registered only in April, and in the temperate continental zone - in April and June. Decreased wind strength and increased air temperature made the cold stress risk lighter in both the duration of the risk periods and the severity of its manifestations. In the last decade of the third climatological normals determination period (1990-2020), the risk of cold exposure has decreased, which is probably reflected in the health status of the population in each climatic zone of the region.

The assessment of influence of weather and climatic conditions, temperature and wind strength in particular, has shown that these indicators play an important part in determining the health risk levels peculiar not only to the subarctic zone, but also to the temperate climate zone. These findings are confirmed by the results reported by other researchers $[8,9$, 16-18, 33]. In the context of our study, we established WCF value for the months of May through September and found no health risks arising therefrom, while other studies (e.g., at high air temperatures) note the positive effect wind strength has on a person's perception of own health status by imbuing the feeling of comfort [29, 30]. In contrast to the studies published by other researchers, we evaluated the role of WCF in conjunction with the extreme values of meteorological factors, i.e. minimum temperature and maximum wind, which allows stating longer duration of seasons when ambient conditions affect human beings negatively.

In addition, we selected WCF based on the priority it takes in the process of assessment of ambient conditions from the point of view of safety of work in the open.

\section{CONCLUSION}

Determination of WCF allows identifying health risk factors and their parameters. At low temperatures, weather-dependent sensations are aggravated by both strong winds and high humidity, which necessitates an extended study to assess the risks peculiar to cold habitats. The results obtained show that the living environment improves, but the underlying changes may have consequences that should be investigated. This methodology can be used to assess public health risks in other climatic zones of the country.

\section{References}

1. de Freitas CR, Grigorieva EA. A comprehensive catalogue and classification of human thermal climate indice. Int J Biometeorol. 2015; 59: 109-20. DOI: 10.1007/s00484-014-0819-3.

2. de Freitas CR, Grigorieva EA. A comparison and appraisal of a comprehensive range of human thermal climate indices. Int $J$ Biometeorol. 2017; 61: 487-512. DOI 10.1007/s00484-0161228-6.

3. Govorushko SM. Vlijanie pogodno-klimaticheskih uslovij na biosfernyj process. Geofizicheskie processy i biosfera. 2012; 11 (11): 5-24. Russian.

4. Dubrovskaya SV. Meteochuvstvitel'nost' i zdorov'e. M.: RIPOL Klassik, 2011; 180 s. Russian.

5. Ohashi Y, Katsuta T, Tani H, Miyashita R. Human cold stress of strong local-wind "Hijikawa-arashi" in Japan, based on the UTCI index and thermo-physiological responses. J Biometeorol. 2018; 62 (7): 1241-50. DOl: 10.1007/s00484-018-1529-z. Epub 2018 Mar 30.

6. Chiu CH. Vagi SJ, Wolkin AF, Martin JP, Noe RS. Evaluation of the National Weather Service Extreme Cold Warning Experiment in North Dakota. Weather, Climate, and Society (Print), 07 Jan 2014, 6: 22-31. DOI: 10.1175/wcas-d-13-00023.1.

7. Ellwanger JH, Chies JAB. Wind: a neglected factor in the spread of infectious diseases. The Lancet. Planetary Health. 2018; 2 (11): e475. Available from: https://doi.org/10.1016/S25425196(18)30238-9.

8. Grigoreva EA. Klimaticheskie uslovija Dal'nego Vostoka kak faktor razvitija boleznej organov dyhanija. Regional'nye problemy. 2017; 20 (4): 79-85. Russian.

9. Grigoreva EA. Klimaticheskaja diskomfortnost' Dal'nego Vostoka

Rossii i zabolevaemost' naselenija. Regional'nye problemy. 2018; 21 (2): 105-12. DOI: 10.31433/1605-220H-2018-21-2-105-112. Russian.

10. Grigoreva EA, Khristoforova NK. Bioclimate of the Russian Far East and public health. Ekologiya cheloveka. Jekologija cheloveka. 2019; 5: 4-10. DOI: 10.33396 / 1728-0869-2019-54-10. Russian.

11. Perevedentsev YuP, Shantalinskiy KM. Monitoring of changes in air temperature and wind speed in the atmosphere of the northern hemisphere over the past decades. Global and regional climate changes. Rossijskij zhurnal prikladnoj jekologii. 2015; 2: 3-8. Russian.

12. Shipko YuV. Specializirovannyj klimaticheskij pokazatel' ocenki bezopasnosti rabot na otkrytom vozduhe $v$ zhestkih holodnyh uslovijah. Geliogeofizicheskie issledovanija. 2014; 9: 161-5. Russian.

13. Shipko YuV, Shuvakin EV, Ivanov AV. Obobshhennyj bioklimaticheskij pokazatel' bezopasnosti rabot na otkrytom vozduhe $v$ surovyh pogodnyh uslovijah. Vestnik KVGU. Serija: geografija. Geojekologija. 2015; 3: 33-39. Russian.

14. Revich BA, Shaposhnikov DA. Osobennosti vozdejstvija voln holoda i zhary na smertnost' $v$ gorodah s rezko-kontinental'nym klimatom. Sibirskoe medicinskoe obozrenie. 2017; 2: 84-90. DOI: 10.20333/2500136-2017-2-84-90. Russian.

15. Revich BA. Shaposhnikov DA, Anisimov OA, Beloluckaya MA. Vlijanie temperaturnyh voln na zdorov'e naselenija $\vee$ gorodah Severo-Zapadnogo regiona Rossii. Problemy prognozirovanija. 2019; 3: 127-34. Russian.

16. Wenz J. What is wind chill, and how does it affect the human 
body? Smithsonian Magazine. January 30, 2019. Available from: https://www.smithsonianmag.com/science-nature/what-windchill-and-how-does-it-affect-human-body-180971376.

17. Ivankov A. Explainer: what is wind chill? What are its effects? Posted on January 31, 2019. Available from: https://www. profolus.com/topics/explainer-what-is-wind-chill-what-are-itseffects.

18. Holmér I. Evaluation of cold workplaces: an overview of standards for assessment of cold stress. Ind Health. 2009; 47 (3): 228-34. DOI: 10.2486/indhealth.47.228.

19. Shipko YuV. Shuvakin EV, Shuvaev MA. Regressionnye modeli ocenkibezopasnosti rabot personala na otkrytoj territorii $v$ zhestkih pogodnyh uslovijah. Vozdushno-kosmicheskie sily. Teorija i praktika. 2017; 1: 131-40. Russian.

20. Siple PA, Passel CF. Measurements of dry atmospheric cooling in sub-freezing temperatures. Proceedings of the American Philosophical Society. 1945; 89: 177-19.

21. GOST R ISO 15743-2012. Prakticheskie aspekty menedzhmenta riska. Menedzhment i ocenka riska dlja holodnyh sred. Dostupno po ssylke: http://docs.cntd.ru/document/1200096448. Russian.

22. Gruza GV, Rankova YeYa. Dinamicheskie klimaticheskie normy temperatury vozduha. Meteorologija i gidrologija. 2012; 12: 5-18. Russian

23. Gruza GV. Nabljudaemye i ozhidaemye izmenenija klimata Rossii: temperatura vozduha. M.: IGKJe Rosgidrometa i RAN, 2012; 193 s. Russian.

24. Monmonier M. Defining the Wind: The beaufort scale, and how a $19^{\text {th }}$ century admiral turned science into poetry. Published online: 29 Feb 2008. Pages 474-475. Available from: https://doi. org/10.1111/j.0033-0124.2005.493_1.x.

25. Rezhimy truda i otdyha rabotajushhih $v$ holodnoe vremja na otkrytoj territorii ili v neotaplivaemyh pomeshhenijah. MR 2.2.7.2129-06. Russian.

26. Mastryukov SI, Chervyakova IV. Obzor sovremennyh

\section{Литература}

1. de Freitas CR, Grigorieva EA. A comprehensive catalogue and classification of human thermal climate indice. Int J Biometeorol. 2015: 59: 109-20. DOI: 10.1007/s00484-014-0819-3.

2. de Freitas CR, Grigorieva EA. A comparison and appraisal of a comprehensive range of human thermal climate indices. Int $J$ Biometeorol. 2017; 61: 487-512. DOI 10.1007/s00484-0161228-6.

3. Говорушко С. М. Влияние погодно-климатических условий на биоссерный процесс. Геосизические процессы и биоссера. 2012; 11 (11): 5-24.

4. Дубровская С. В. Метеочувствительность и здоровье. М.: РИПОЛ Классик, 2011; 180 с.

5. Ohashi $\mathrm{Y}$, Katsuta T, Tani H, Miyashita R. Human cold stress of strong local-wind "Hijikawa-arashi" in Japan, based on the UTCI index and thermo-physiological responses. J Biometeorol. 2018; 62 (7): 1241-50. DOI: 10.1007/s00484-018-1529-z. Epub 2018 Mar 30

6. Chiu CH. Vagi SJ, Wolkin AF, Martin JP, Noe RS. Evaluation of the National Weather Service Extreme Cold Warning Experiment in North Dakota. Weather, Climate, and Society (Print), 07 Jan 2014, 6: 22-31. DOI: 10.1175/wcas-d-13-00023.1.

7. Ellwanger $\mathrm{JH}$, Chies JAB. Wind: a neglected factor in the spread of infectious diseases. The Lancet. Planetary Health. 2018; 2 (11): e475. Available from: https://doi.org/10.1016/S25425196(18)30238-9.

8. Григорьева Е. А. Климатические условия Дальнего Востока как фактор развития болезней органов дыхания. Региональные проблемы. 2017; 20 (4): 79-85.

9. Григорьева Е. А. Климатическая дискомфортность Дальнего Востока России и заболеваемость населения. Региональные проблемы. 2018; 21 (2): 105-12. DOI: 10.31433/1605-220X2018-21-2-105-112.

10. Григорьева Е. А., Христофорова Н. К. Биоклимат Дальнего Востока России и здоровье населения. Экология человека. otechestvennyh i zarubezhnyh metodov ocenki vetrovogo ohlazhdenija cheloveka. Navigacija i gidrografija. 2014; 38: 8390. Russian.

27. Roshan G, Mirkatouli G, Shakoor A, Mohammad-Nejad V. Studying Wind Chill Index as a Climatic Index Effective on the Health of Athletes and Tourists Interested in Winter Sports. Asian J Sports Med. 2010; 1 (2): 108-16. DOI: 10.5812/asjsm.34861.

28. Morris DM, Pilcher JJ, Powell RB. Task-dependent cold stress during expeditions in Antarctic environments. Int $\mathrm{J}$ Circumpolar Health. 2017; 76 (1): 1379306. Available from: http://dx.doi.org/1 $0.1080 / 22423982.2017 .1379306$

29. Amineva AA, Ilbulova GR, Yagafarova GA, Kuzhina GSh Ocenka komfortnosti pogodno-klimaticheskih uslovij Respubliki Bashkortostan po vetro-holodovomu indeksu. Doklady Bashkirskogo universiteta. 2017; 2 (3): 391-6. Russian.

30. Sinicyn IS, Georgica IM, Ivanova TG. Bioklimaticheskaja harakteristika territorii v mediko-geograficheskih celjah. Jaroslavskij pedagogicheskij vestnik. 2013; 3 (4): 279-283. Russian.

31. Kuzyakina MV, Gura DA. Ocenka komfortnosti bioklimaticheskih uslovij Krasnodarskogo kraja s primeneniem GIS-tehnologij. Jug Rossii: jekologija, razvitie. 2020; 15 (3): 66-76. Available from: https://doi.org/10.18470/1992-1098-2020-3-66-76. Russian.

32. Report on Wind Chill Temperature and extreme heat indices: Evaluation and improvement projects. U.S. Department of Commerce. National Oceanic and Atmospheric Administration, Office of the Federal Coordinator for Meteorological Services and Supporting Research, FCM-R19-2003. Washington D.C; 2003. $75 \mathrm{p}$.

33. Chernova EV. Analiz bioklimaticheskih uslovij goroda Ishima po vetro-holodovomu indeksu Sajpla-Passela. Materialy mezhdunarodnoj nauchno-prakticheskoj konferencii «Kozybaevskie chtenija - 2015: Perspektivy razvitija nauki i obrazovanija». 2016: 218-221. Available from: http://repository.nkzu.kz/id/eprint/ 6391. Russian.
2019; 5: 4-10. DOI: 10.33396 / 1728-0869-2019-5-4-10.

11. Переведенцев Ю. П., Шанталинский К. М. Мониторинг изменений температуры воздуха и скорости ветра в атмосфере Северного полушария за последние десятилетия. Глобальные и региональные изменения климата. Российский журнал прикладной экологии. 2015; 2: 3-8.

12. Шипко Ю. В. Специализированный климатический показатель оценки безопасности работ на открытом воздухе в жестких холодных условиях. Гелиогеосизические исследования. 2014; 9: 161-5.

13. Шипко Ю. В., Шувакин Е. В., Иванов А. В. Обобщенный биоклиматический показатель безопасности работ на открытом воздухе в суровых погодных условиях. Вестник КВГУ. Серия: география. Геоэкология. 2015; 3: 33-39.

14. Ревич Б. А., Шапошников Д. А. Особенности воздействия волн холода и жары на смертность в городах с резкоконтинентальным климатом. Сибирское медицинское обозрение. 2017; 2: 84-90. DOI: 10.20333/2500136-2017-284-90

15. Ревич Б. А. Шапошников Д. А., Анисимов О. А., Белолуцкая М. А. Влияние температурных волн на здоровье населения в городах Северо-Западного региона России. Проблемь прогнозирования. 2019; 3: 127-34.

16. Wenz J. What is wind chill, and how does it affect the human body? Smithsonian Magazine. January 30, 2019. Available from: https://www.smithsonianmag.com/science-nature/what-windchill-and-how-does-it-affect-human-body-180971376.

17. Ivankov A. Explainer: what is wind chill? What are its effects? Posted on January 31, 2019. Available from: https://www. profolus.com/topics/explainer-what-is-wind-chill-what-are-itseffects.

18. Holmér I. Evaluation of cold workplaces: an overview of standards for assessment of cold stress. Ind Health. 2009; 47 (3): 228-34. DOI: 10.2486/indhealth.47.228. 
19. Шипко Ю. В. Шувакин Е. В., Шуваев М. А. Регрессионные модели оценкибезопасности работ персонала на открытой территории в жестких погодных условиях. Воздушнокосмические силы. Теория и практика. 2017; 1: 131-40.

20. Siple PA, Passel CF. Measurements of dry atmospheric cooling in sub-freezing temperatures. Proceedings of the American Philosophical Society. 1945; 89: 177-19.

21. ГОСТ Р ИСО 15743-2012. Практические аспекть менеджмента риска. Менеджмент и оценка риска для холодных сред. Доступно по ссылке: http://docs.cntd.ru/ document/1200096448

22. Груза Г. В., Ранькова Э. Я. Динамические климатические нормы температуры воздуха. Метеорология и гидрология. 2012; 12: 5-18.

23. Груза Г. В. Наблюдаемые и ожидаемые изменения климата России: температура воздуха. М.: ИГКЭ Росгидромета и РАН, 2012; 193 c.

24. Monmonier M. Defining the Wind: The beaufort scale, and how a $19^{\text {th }}$ century admiral turned science into poetry. Published online: 29 Feb 2008. Pages 474-475. Available from: https://doi. org/10.1111/j.0033-0124.2005.493_1.x.

25. Режимы труда и отдыха работающих в холодное время на открытой территории или в неотапливаемых помещениях. MP 2.2.7.2129-06

26. Мастрюков С. И., Червякова И. В. Обзор современных отечественных и зарубежных методов оценки ветрового охлаждения человека. Навигация и гидрография. 2014; 38 83-90.

27. Roshan G, Mirkatouli G, Shakoor A, Mohammad-Nejad V. Studying Wind Chill Index as a Climatic Index Effective on the
Health of Athletes and Tourists Interested in Winter Sports. Asian J Sports Med. 2010; 1 (2): 108-16. DOI: 10.5812/asjsm.34861.

28. Morris DM, Pilcher JJ, Powell RB. Task-dependent cold stress during expeditions in Antarctic environments. Int J Circumpolar Health. 2017; 76 (1): 1379306. Available from: http://dx.doi.org/1 0.1080/22423982.2017.1379306.

29. Аминева А. А., Ильбулова Г. Р., Ягафарова Г. А., Кужина Г. Ш. Оценка комфортности погодно-климатических условий Республики Башкортостан по ветро-холодовому индексу. Доклады Башкирского университета. 2017; 2 (3): 391-6.

30. Синицын И. С., Георгица И. М., Иванова Т. Г. Биоклиматическая характеристика территории в медико-географических целях. Ярославский педагогический вестник. 2013; 3 (4): 279-283.

31. Кузякина М. В., Гура Д. А. Оценка комфортности биоклиматических условий Краснодарского края с применением ГИС-технологий. Юг России: экология, развитие. 2020; 15 (3): 66-76. Available from: https://doi. org/10.18470/1992-1098-2020-3-66-76.

32. Report on Wind Chill Temperature and extreme heat indices: Evaluation and improvement projects. U.S. Department of Commerce. National Oceanic and Atmospheric Administration, Office of the Federal Coordinator for Meteorological Services and Supporting Research, FCM-R19-2003. Washington D.C; 2003. $75 \mathrm{p}$.

33. Чернова Е. В. Анализ биоклиматических условий города Ишима по ветро-холодовому индексу Сайпла-Пассела. Материалы международной научно-практической конференции «Козыбаевские чтения - 2015: Перспективы развития науки и образования». 2016: 218-221. Доступно по ссылке: http:// repository.nkzu.kz/id/eprint/ 6391. 